\section{Identifying Superior Snow Pea Breeding Lines}

\author{
Antonio M. De Ron, ${ }^{1}$ Jorge J. Magallanes, ${ }^{2}$ Óscar Martínez, \\ Paula Rodiño, and Marta Santalla \\ Plant Genetic Resources Department, Misión Biológica de Galicia-CSIC, P.O. \\ Box 28, 36080 Pontevedra, Spain
}

Additional index words. Pisum sativum, edible-pod, multivariate analysis, quality

\begin{abstract}
We evaluated 33 edible-pod pea (Pisum sativum L.) lines selected from single plants within 11 snow pea landraces and three elite cultivars for their horticultural value in three field trials at Pontevedra and Lugo (northwestern Spain). Field performance was estimated according to six traits related to earliness and duration, while horticultural value was determined by five pod traits. The global pod quality was estimated by a taste panel. Lines showed significant differences in nine quantitative traits. Significant differences were found among means of five landraces and the lines selected within them for pod length, width and weight. Cluster and principal component analysis identified a main group of 16 lines derived mainly from landraces PSM-0112 and PSM-0227 that had desirable earliness and pod quality. Some of the lines, such as MB-0298, MB-0324, MB-0325, MB-0326, MB-0332, and $\mathrm{MB}-0334$ are appropriate for vegetable production as edible pod snow pea varieties and for use in breeding programs. Moreover, the lines MB-0298, MB-0321, MB-0322, and MB-0324 showed stable earliness and MB-0330 and MB-0332 stable pod quality across the three environments evaluated.
\end{abstract}

Edible-pod peas (Pisum sativum L.) are grown for their tender fresh pods that lack the parchment layer inside the pod (Sneddon, 1970). This type of pea must meet several pod quality requirements including pod size, fresh weight and shape, texture and the absence of the parchment layer. The two types of edible podded pea are snow peas, which have thin walls, and snap peas with thick pod walls. The combination of two or three genes contribute to making the pod suitable for consumption in the fresh stage: the gene $p$ (that mostly eliminates the schlerenchymatous membrane of inner pod wall), the gene $v$ (that reduces pod wall parchment) and the gene $n$ (responsible for thick and fleshy pod walls) (McGee and Baggett, 1992, Myers et al., 2001).

In Spain, only a few improved cultivars of edible-pod peas (snow pea type) are currently grown commercially. Nevertheless, in Northwestern Spain and North of Portugal, snow pea is a traditional vegetable often grown in small gardens and present in fresh markets. Snow pea could be a winter and spring alternative crop as complement to other popular vegetables such as snap bean, as it can be produced in open fields during cool growing seasons. The improvement of pod quality and agronomic performance are the major breeding objectives in snow pea.

Received for publication 16 Dec. 2004. Accepted for publication 25 Jan. 2005. Research was supported by the Projects XUGA40302B94 and XUGA40302B96 from the Government of Galicia (Spain). Jorge J. Magallanes thanks two grants from the University of Santiago de Compostela (Spain) and the University San Luis Gonzaga (Peru). We are grateful to James R. Myers and Pedro Revilla for reviewing the manuscript and to CRF-INIA (Spain) for supplying pea germplasm.

${ }^{1}$ To whom reprint requests should be addressed; e-mail amderon@mbg.cesga.es.

${ }^{2}$ Current address: Faculty of Agronomy, University San Luis Gonzaga, Ica, Peru.
Most pea varieties grown in these Spanish lines and can be considered as unimproved landraces (Santalla et al., 2001). Farmers used to save some seeds from the harvest for planting the next year. These traditional landraces or heirloom cultivars are an important genetic resource for plant breeders because of their considerable genotypic variation and their adaptation to environmental conditions after many years of cultivation (Amurrio et al., 1993, 2000, Myers et al., 2001). Environmental effects and genotype by environment interactions could affect the stability of quantitative traits that are important for genetic improvement (Lin et al., 1986). The comparison of different lines or varieties in different environments results in a range of scores which could cause difficulty in identifying the superiority of any variety. Therefore, the performance of such lines or varieties should be verified under various environmental conditions.

The objectives of this research were to report selection of lines within snow pea landraces and to evaluate these edible-podded lines for horticultural traits focused to their use in vegetable production in different areas and to assess their potential role in future pea breeding programs.

\section{Material and Methods}

The Misión Biológica de Galicia (MBG) of the Spanish Council for Scientific Research (CSIC) in Pontevedra (Spain) has a germplasm collection of pea that includes 237 accessions for human consumption (fresh seed and fresh pod), animal feed (dry seed), and mixtures of types (Santalla et al., 2001). From this collection, 11 accessions (PSM code) from Spain and Portugal were identified as edible podded snow pea landraces (Amurrio et al., 1993, 1996) and were the basis for the present research. Thirtyand Portuguese regions are mixtures of pure three lines (MB code) were derived from those eleven landraces in 1995 and 1998. Each line was derived by single plant selection within the respective landrace.

These lines and three elite cultivars (' $\mathrm{Ca}$ puchino', 'Carouby', and 'Tirabeque') were evaluated in three winter field trials in different environments: Pontevedra in 1998-99 and 2000-01 (Spain, lat. $42^{\circ} 26^{\prime} \mathrm{N}$, long. $8^{\circ} 38^{\prime} \mathrm{W}$, 20 masl, average temperature $18.6^{\circ} \mathrm{C}$, annual rainfall $1600 \mathrm{~mm}$ ) and Lugo in 1998-99 (Spain, lat. $43^{\circ} 00^{\prime} \mathrm{N}$, long. $7^{\circ} 33^{\prime} \mathrm{W}, 450$ masl, average temperature $11.6^{\circ} \mathrm{C}$, annual rainfall $800 \mathrm{~mm}$ ). The experimental design was a randomized complete block with two replications and 16 plants/plot (spaced $0.25 \times 0.25 \mathrm{~m}$ ) in the 1998-99 trials and 45 plants $/$ plot (spaced $0.80 \times 0.10 \mathrm{~m}$ ) in the trial of $2000-01$. The trials represented a plant density of 160,000 plants/ha and 125,000 plants/ha, respectively; a difference that probably does not significantly influence productivity and agronomic performance because of plant compensation for population differences (Meadley and Milbourn, 1970).

Eleven quantitative traits were measured or calculated on an average plot basis. During the development of the crop, days to first flower, days to flowering $(50 \%$ of plants have at least one open flower), and duration of flowering (days to $50 \%$ flowering until $50 \%$ of plants have flower abscission) were measured. At the fresh pod consumption stage (when pods attain the maximum size at the beginning of seed development) the following traits: days to first pod, days to maturity of fresh pods on $50 \%$ of the plants, days to end of pod production in $50 \%$ of the plants, pod length $(\mathrm{mm})$, pod width from suture to suture $(\mathrm{mm})$, pod weight $(\mathrm{g})$, pod soluble solids content measured by a hand refractometer (\%) and pod texture measured with a tenderometer $\left(72 \mathrm{~kg} \cdot \mathrm{cm}^{-2}\right)$ were determined. Global pod quality at the consumption stage was assessed by a trained panel of tasters as described by De Ron et al. (2000) on the basis of four subjective traits (texture, hardness, fibrousness and taste; using a 1 to 5 scale for each trait) that sum for the global quality or GQ (scored from 4 = poor to $20=$ excellent).

Analysis of variance was performed using the SAS statistical package (SAS Institute, 2000) and environments were considered as a random factor and lines as a fixed factor. Mean comparisons were performed by Student's $t$ test according to Steel et al. (1997). Cluster analysis by the UPGMA procedure and principal component analysis were made using the NTSYS-pc package (Rohlf, 2000).

\section{Results and Discussion}

Pea landraces from different areas of Spain and Portugal often have intra-landrace variation both in phenotype and isozyme profile(Varela et al., 1997). Several breeding lines were selected within heterogeneous landraces that exhibited a good horticultural performance in previous studies (Amurrio et al., 1996).

Table 1 displays the analysis of variance over three environments. Differences among lines were significant for all the traits with the exception of soluble solids and pod texture. This 
suggests that both characters are probably not reliable indicators of variation in pod quality for fresh consumption in the studied pea germplasm. Significant differences among environments were found for all traits except for pod width, soluble solids and pod texture and line by environment interaction was significant for all traits except for fresh pod maturity, pod width and pod texture. Therefore, most of traits exhibited stability across the three environments. Significant environmental effects and interactions in traits including earliness and pod quality could be due to wide differences between the environmental conditions of Pontevedra (1999 and 2001 trials) and Lugo (1999 trial). Temperature and rainfall during the cool season was lower in Lugo than in Pontevedra. Amurrio et al. (1993) also found significant interaction in quantitative traits for pea germplasm under different environments: greenhouse winter planting, open-field winter planting, and open-field spring planting. These interactions agree with the results by Snoad and Arthur (1974). The displayed environmental effects and interactions between genotype and environment highlight the different response of the pea lines to the environmental conditions. This means that the best genotype for one en- vironment is not the best for another (Falconer and McKay, 1996). With regard to pod length, cultivars such as 'Capuchino' $(137.5 \mathrm{~mm})$ and 'Carouby' (122.5 mm), and line MB-0333 $(120.5 \mathrm{~mm})$ showed the best values in Lugo 1998-99, and concerning to days to first flower, 'Capuchino' (75.0 d), MB-0171 (77.5 d) and MB-0280 (77.5 d) were the earliest lines. A limited plasticity of some lines is derived from this research. Four of them, namely MB-0298, MB-0321, MB-0322, and MB-0334 expressed consistent earliness while MB-0324, MB-0329, and MB-0330 expressed stable pod attributes across the three environments.

Three pod traits were used to indicate quality for fresh pod production: length, width and five pod weight. Table 2 shows the difference in these traits between the landraces and the lines derived from them. The lines that showed significant differences with the landraces were derived from PSM-0022 (2 lines), PSM-0066 (4 lines), PSM-0102(2 lines), PSM-0112(11 lines), PSM-0191 (2 lines) and PSM-0227 (3 lines). Lines derived from landraces PSM-0070, PSM0110, PSM-0111, PSM-0118, and PSM-0125 exhibited no significant mean differences with the landraces. Pod length and weight showed higher differences between lines and landraces than pod width. The lines derived from landraces PSM-0102 and PSM-0227 displayed the highest differences in pod length and weight that indicates the value of these two snow pea landraces for genetic improvement. Landraces PSM-0070 and PSM-0118 exhibited good values for pod traits which indicates their breeding value. Nevertheless, for vegetable production the use of homogeneous snow pea lines should be more convenient than landraces due to the variation within the latter (Varela et al., 1997).

Global quality and the means for nine significant quantitative traits measured on the 33 lines and three cultivars are shown in Table 3 . Six characters (first flower, beginning of flowering, duration of flowering, first fresh pod, maturity for fresh pod and end of fresh pod production) were measured to provide a detailed information about traits related to the earliness and duration of pod production of the lines. Pod quality was based on four characters: length, width, weight and global quality. The five lines MB-0292, MB-0321, MB-0322, MB-0326, and MB-0334 showed the best values for earliness and they were similar to 'Capuchino'. The best ranked lines for pod quality were MB-0324, MB-0325,

Table 3. Means of quantitative traits and global quality evaluated for edible-pod pea lines and elite cultivars in three environments.

\begin{tabular}{|c|c|c|c|c|c|c|c|c|c|c|}
\hline \multirow[b]{2}{*}{ Line } & \multicolumn{10}{|c|}{ Trait $^{2}$} \\
\hline & $\begin{array}{l}\text { FF } \\
\text { (d) }\end{array}$ & $\begin{array}{l}\text { BF } \\
\text { (d) }\end{array}$ & $\begin{array}{l}\text { DF } \\
\text { (d) }\end{array}$ & $\begin{array}{l}\text { FP } \\
\text { (d) }\end{array}$ & $\begin{array}{l}\text { MP } \\
\text { (d) }\end{array}$ & $\begin{array}{l}\text { EP } \\
\text { (d) }\end{array}$ & $\begin{array}{c}\mathrm{PL} \\
(\mathrm{mm})\end{array}$ & $\begin{array}{c}\text { PW } \\
(\mathrm{mm})\end{array}$ & $\begin{array}{c}5 \mathrm{PW} \\
(\mathrm{g})\end{array}$ & $\begin{array}{c}\text { GQ } \\
(4-20)\end{array}$ \\
\hline$\overline{\mathrm{MB}-0113}$ & 109.3 & 118.2 & 28.7 & 126.0 & 132.0 & 153.0 & 97.1 & 17.9 & 16.3 & 12.6 \\
\hline MB-0114 & 104.0 & 115.2 & 32.7 & 122.3 & 132.8 & 152.8 & 100.1 & 18.5 & 17.1 & 11.5 \\
\hline MB-0115 & 113.2 & 114.3 & 29.0 & 122.0 & 135.3 & 154.8 & 106.2 & 18.8 & 18.1 & 12.6 \\
\hline MB-0116 & 111.8 & 117.5 & 27.2 & 123.8 & 132.3 & 153.5 & 101.5 & 18.0 & 17.5 & 13.9 \\
\hline MB-0117 & 102.3 & 106.7 & 35.8 & 122.2 & 131.8 & 150.8 & 87.0 & 17.6 & 12.7 & 11.1 \\
\hline MB-0118 & 105.5 & 110.5 & 32.8 & 123.7 & 131.0 & 150.2 & 85.7 & 16.7 & 12.4 & 11.2 \\
\hline MB-0119 & 105.8 & 109.5 & 34.2 & 121.0 & 130.8 & 150.5 & 103.3 & 19.5 & 17.3 & 12.8 \\
\hline MB-0120 & 106.8 & 112.3 & 31.7 & 121.5 & 130.7 & 150.5 & 95.8 & 18.8 & 16.1 & 13.2 \\
\hline MB-0121 & 105.0 & 109.2 & 36.3 & 121.2 & 131.2 & 152.7 & 82.6 & 16.2 & 10.5 & 10.9 \\
\hline MB-0164 & 97.7 & 102.2 & 38.2 & 113.7 & 140.2 & 153.0 & 98.5 & 18.4 & 17.7 & 12.2 \\
\hline MB-0167 & 94.5 & 99.2 & 42.5 & 107.5 & 120.7 & 149.7 & 108.8 & 22.6 & 24.8 & 13.3 \\
\hline MB-0171 & 88.2 & 104.8 & 43.7 & 112.8 & 127.7 & 153.8 & 90.7 & 18.2 & 15.5 & 8.9 \\
\hline MB-0188 & 94.7 & 100.3 & 41.3 & 108.3 & 122.3 & 149.2 & 100.6 & 21.5 & 23.1 & 13.7 \\
\hline MB-0280 & 85.8 & 102.3 & 46.8 & 106.2 & 133.2 & 150.2 & 83.5 & 16.7 & 11.0 & 12.2 \\
\hline MB-0290 & 94.5 & 97.7 & 39.8 & 109.0 & 126.3 & 149.0 & 102.8 & 20.5 & 19.6 & 12.4 \\
\hline MB-0292 & 92.5 & 97.5 & 43.5 & 102.8 & 121.7 & 148.2 & 98.8 & 21.4 & 19.3 & 11.4 \\
\hline MB-0298 & 91.5 & 96.8 & 44.8 & 105.2 & 121.5 & 148.2 & 109.5 & 21.1 & 24.0 & 13.9 \\
\hline MB-0319 & 116.7 & 120.8 & 27.3 & 122.2 & 134.2 & 155.3 & 112.4 & 19.3 & 19.7 & 12.0 \\
\hline MB-0320 & 90.8 & 98.0 & 43.7 & 109.0 & 126.5 & 150.3 & 102.3 & 21.7 & 20.8 & 12.0 \\
\hline MB-0321 & 88.5 & 92.7 & 42.5 & 104.0 & 116.5 & 141.3 & 103.8 & 20.5 & 22.1 & 12.3 \\
\hline MB-0322 & 88.0 & 93.3 & 46.2 & 103.8 & 121.0 & 146.7 & 104.7 & 18.2 & 23.4 & 13.1 \\
\hline MB-0323 & 91.8 & 101.3 & 39.8 & 108.2 & 122.3 & 147.3 & 93.6 & 20.1 & 17.0 & ---.y \\
\hline MB-0324 & 94.5 & 100.5 & 39.3 & 107.5 & 122.7 & 147.0 & 115.1 & 21.3 & 30.7 & 15.6 \\
\hline MB-0325 & 95.8 & 99.8 & 41.8 & 109.2 & 125.0 & 147.5 & 113.4 & 23.0 & 24.9 & 14.2 \\
\hline MB-0326 & 91.7 & 91.8 & 49.5 & 105.5 & 121.7 & 147.0 & 101.8 & 22.4 & 24.4 & 11.9 \\
\hline MB-0327 & 93.8 & 97.3 & 43.2 & 106.0 & 121.8 & 148.3 & 103.4 & 22.1 & 26.0 & 13.5 \\
\hline MB-0328 & 93.7 & 97.3 & 45.3 & 107.0 & 120.2 & 148.7 & 102.4 & 22.6 & 25.6 & 13.6 \\
\hline MB-0329 & 101.8 & 105.5 & 36.8 & 112.3 & 126.3 & 149.3 & 116.8 & 21.4 & 27.1 & 11.4 \\
\hline MB-0330 & 93.5 & 97.5 & 37.7 & 104.5 & 122.3 & 148.8 & 114.2 & 22.7 & 27.9 & 12.7 \\
\hline MB-0331 & 94.7 & 98.5 & 41.7 & 106.0 & 122.3 & 145.8 & 110.6 & 20.7 & 25.4 & --- \\
\hline MB-0332 & 96.0 & 98.7 & 42.3 & 107.0 & 118.8 & 146.2 & 115.0 & 20.7 & 27.1 & 14.6 \\
\hline MB-0333 & 93.7 & 98.0 & 46.7 & 105.2 & 122.8 & 150.3 & 114.3 & 22.7 & 23.9 & 12.9 \\
\hline MB-0334 & 90.2 & 94.7 & 46.3 & 105.0 & 120.7 & 148.0 & 104.0 & 22.2 & 20.7 & 13.2 \\
\hline Capuchino & 88.7 & 95.3 & 46.5 & 103.7 & 122.3 & 147.7 & 118.6 & 21.4 & 29.9 & --- \\
\hline Carouby & 92.2 & 98.2 & 40.7 & 106.7 & 119.7 & 145.3 & 107.9 & 20.4 & 23.8 & 14.4 \\
\hline Tirabeque & 93.7 & 98.7 & 40.5 & 102.7 & 121.0 & 146.5 & 89.2 & 18.8 & 19.3 & 10.1 \\
\hline Mean & 97.0 & 102.6 & 39.6 & 111.2 & 125.8 & 149.4 & 102.7 & 20.1 & 20.9 & 12.6 \\
\hline $\operatorname{LSD}(5 \%)^{x}$ & 9.2 & 9.9 & 10.5 & 10.5 & 8.3 & 4.8 & 11.3 & 2.5 & 6.1 & \\
\hline
\end{tabular}

${ }^{\mathrm{z} F F}=$ first flower, $\mathrm{BF}=$ beginning of flowering, $\mathrm{DF}=$ duration of flowering, $\mathrm{FP}=$ first fresh pod, $\mathrm{MP}=$ maturity for fresh pod, $\mathrm{EP}=$ end of fresh pod production, $\mathrm{PL}=$ pod length, $\mathrm{PW}=$ pod width, $5 \mathrm{PW}=$ five pods weight, $\mathrm{GQ}=$ pod global quality.

${ }^{\mathrm{y}}$ Missing values.

${ }^{\mathrm{L}} \mathrm{LSD}=$ least significant difference. 
and MB-0332. These lines surpassed the values of 'Carouby', the best commercial cultivar. These eight lines could be good parents for use in breeding programs. MB-0298, MB-0322, and MB-0334 lines displayed sufficient earliness (96.8, 93.3, and 94.7 $\mathrm{d}$ to beginning of flowering, respectively), long pods (109.5, 104.7, and $104.0 \mathrm{~mm}$ respectively) and high global quality $(13.9,13.1$, and 13.3 respectively), and they could be candidates for commercial use in Northern Spain and Portugal.

The structure of phenotypic variation found in the lines is shown by a dendrogram arising from UPGMAcluster analysis and the principal component plot. The cluster analysis (Fig. 1) classified the lines and elite cultivars into nine groups ( $\mathrm{C} 1$ to $\mathrm{C} 9)$ that differ in some relevant traits that are reflected in the first (earliness and cycle related traits) and second (pod length and width, and five pod weight) principal components. The fit between the cophenetic value matrix and the dendrogram matrix was good according to the cophenetic correlation coefficient (0.886). Plotting the clusters of lines against the first and second principal components (accounting for $68.2 \%$ and $19.2 \%$ of variation respectively) orders the lines according to earliness and pod quality traits (Fig. 2).
Selection of pea in small farms and gardens over a long period of time has contributed to development of landraces or heirloom varieties adapted to specific environments. Pea landraces are sometimes grown as unimproved populations or mixtures in many small farms in the north of Spain and Portugal and they may have multiple uses (Santalla et al., 2001). Mixed pea landraces from the MBG-CSIC germplasm collection, described by Amurrio et al. (1993), provide an opportunity for breeding for different purposes such as fresh and dry seed and fresh edible pod. This permitted an intrapopulation selection program and selection of different

Table 1. Analysis of variance of quantitative traits for edible-pod pea lines and elite cultivars evaluated in three environments.

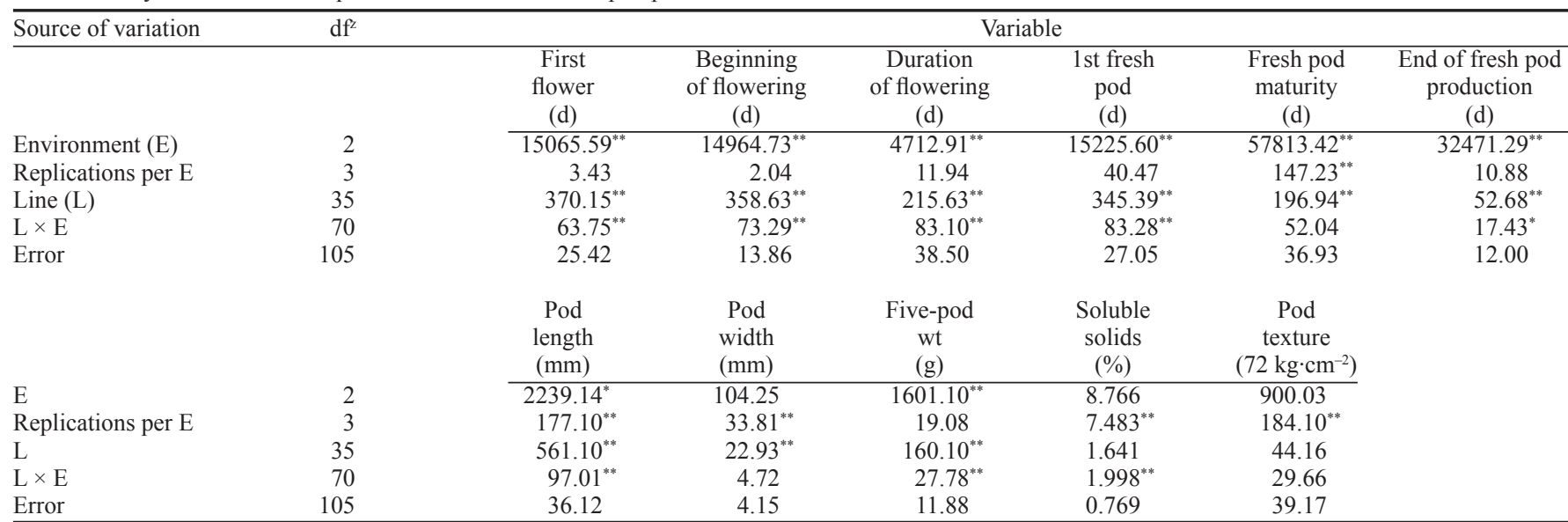

${ }^{\mathrm{z}} \mathrm{df}=$ Degrees of freedom.

**** Significant at $P \leq 0.05$ or 0.01 , respectively.

Table 2. Comparison of edible-pod pea lines and original landraces for pod traits.

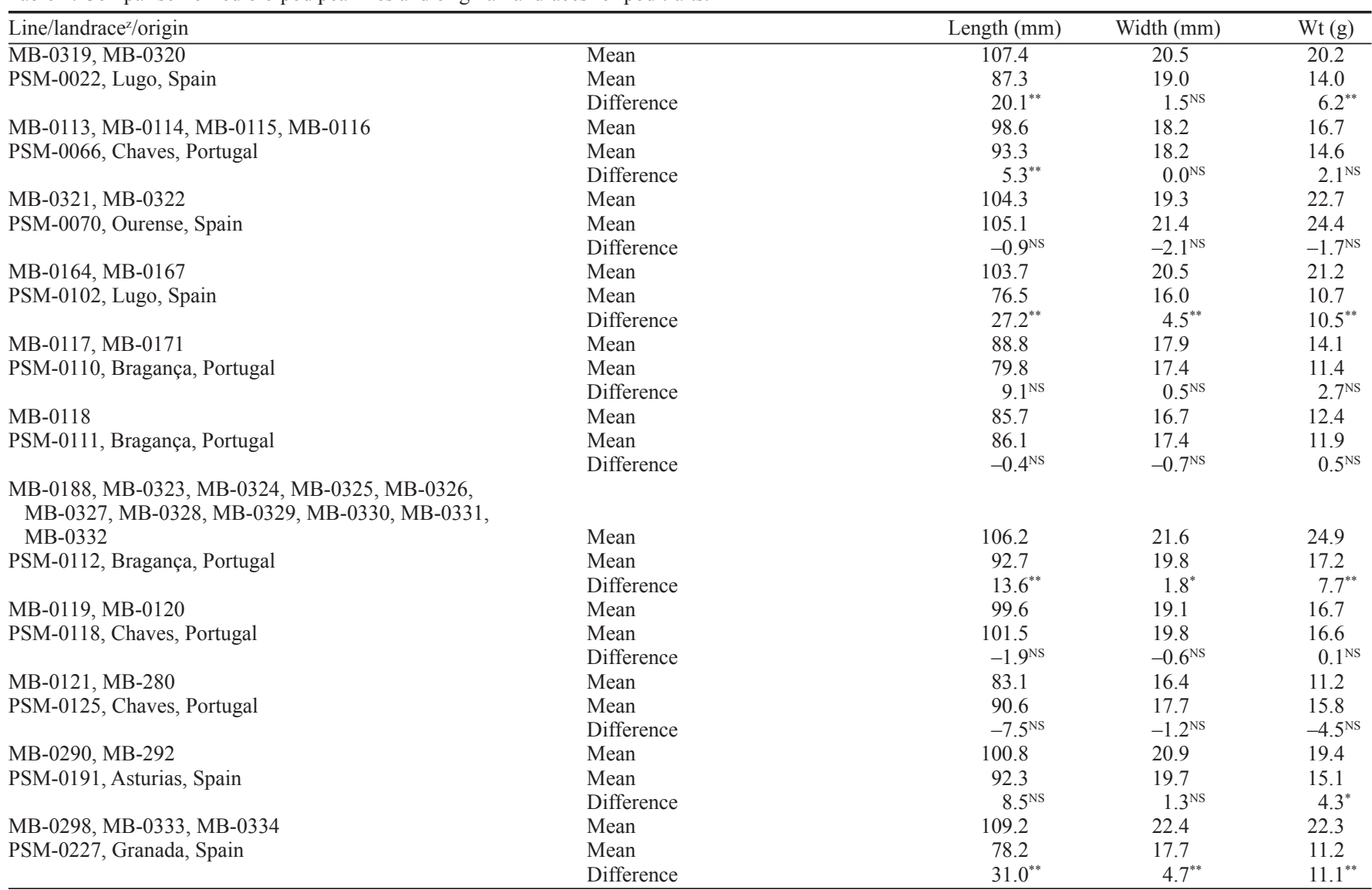

${ }^{2}$ Amurrio et al. (1996)

NS,"****Nonsignificant or significant at $P \leq 0.05$ or 0.01 , respectively. 


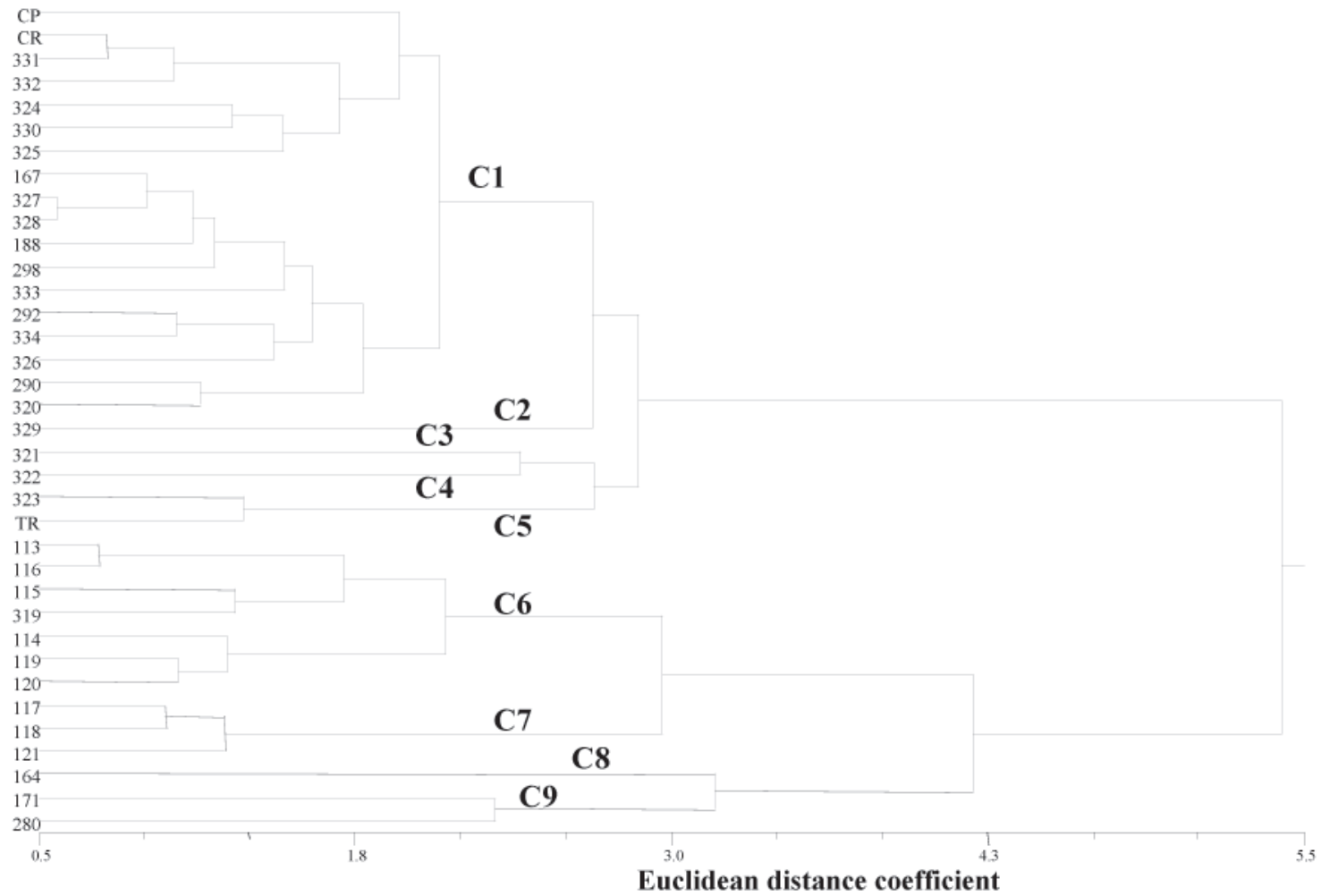

Fig. 1. Dendrogram showing the clustering ( $\mathrm{C} 1$ to $\mathrm{C} 9$ ) of edible-pod lines (numbers plus $\mathrm{MB}=$ represent the code of the lines) and elite cultivars ( $\mathrm{CP}=$ 'Capuchino', $\mathrm{CR}=$ 'Carouby', $\mathrm{TR}=$ 'Tirabeque') evaluated.

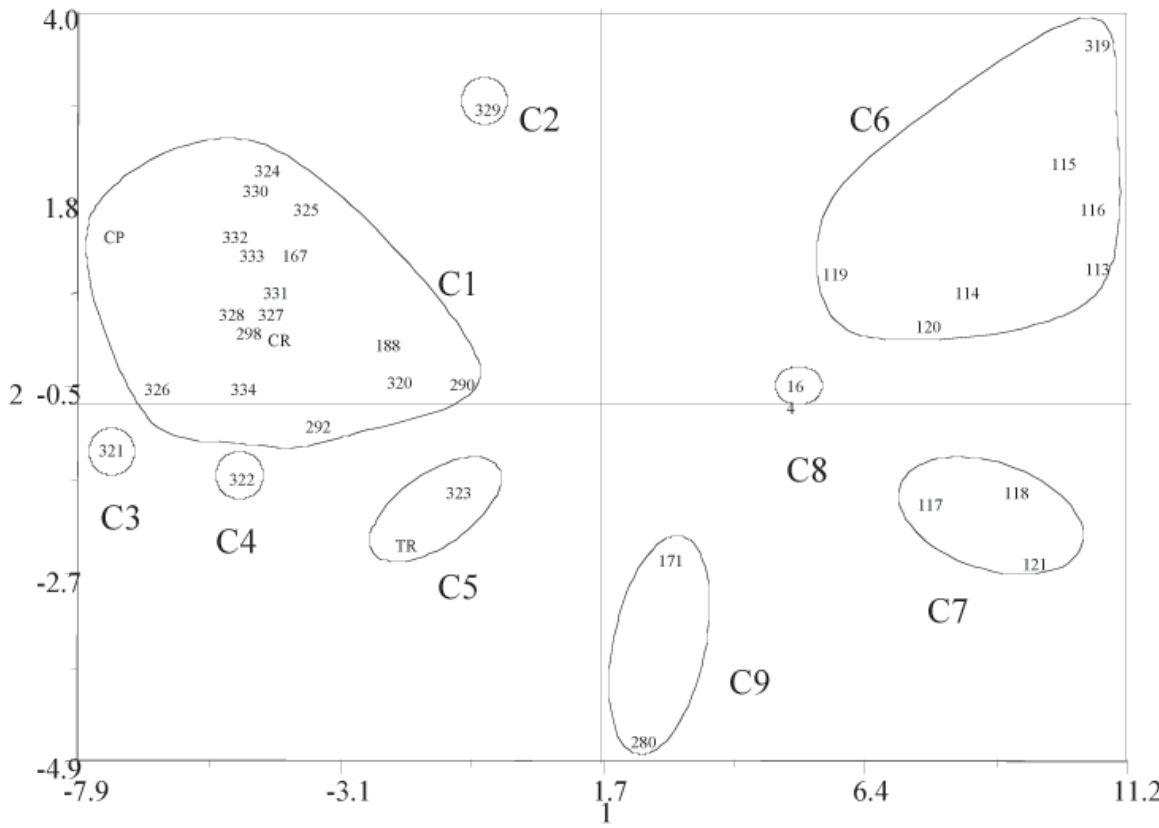

from the landrace PSM-0227) had desirable scores for earliness, pod traits, and global quality. Group C6 also showed a trend towards grouping lines from the same origin(MB-0113, MB-0114, MB-0115, and MB-0116 from PSM-0066; MB0119, and MB-0120 from PSM-0118) with a medium pod quality and long pod fill duration. The remainder of the lines were clustered in small groups as outliers of the main clusters and possessed no significant breeding value. MB0329 (C2), an exception, presented intermediate earliness and very good pod value.

Adaptation to different environments of snow pea lines displaying acceptable agronomic value and high pod quality as well as a limited plasticity of some lines is derived from this study. This work suggests that phenotypic selection for agronomic and horticultural performance within pea landraces, has resulted in a group of very good snow pea lines. Some of the lines evaluated are useful for vegetable commercial production in different areas or as parents for further breeding for agronomic performance and pod quality.

\section{Literature Cited}

Amurrio, J.M., A.M. De Ron, and M.R. Escribano. 1993. Evaluation of Pisum sativum landraces from the Northwest of the Iberian peninsula and their breeding value. Euphytica 66:1-10.

. 2. Principal component $(\mathrm{PC})$ plot showing the distribution of edible-pod lines (numbers plus $\mathrm{MB}=$ code of the lines) and elite cultivars $(\mathrm{CP}=$ 'Capuchino', $\mathrm{CR}=$ 'Carouby', $\mathrm{TR}=$ 'Tirabeque') evaluated according to the first (1) and second (2) principal components. Clusters derived from the dendrogram are indicated around the lines and cultivars ( $\mathrm{C} 1$ to $\mathrm{C} 9)$.

lines that, in this analysis plotted distinctly such as MB-0167 and MB-0164 (from landrace PSM-0102), MB-0319, and MB-0320 (from landrace PSM-0022), and MB-0121 and MB0280 (from PSM-0125). However, selection in other landraces resulted in lines that clustered close together such as those derived from PSM0112 (most belong to group C1), PSM-0227,
PSM-0191, PSM-0066, and PSM-0118. These landraces must be considered more homogeneous as indicated by intravarietal phenotypic variation.

With regard to the clusters, 16 lines from three landraces and with 'Capuchino' and 'Carouby', are included in C1. Of these lines, MB-0298, MB-0333, and MB-0334 (originated
Amurrio, J.M., A.M. De Ron, and J. HernándezNistal. 2000. How to identify edible-pod pea varieties in a germplasm collection. Pisum Genetics 32:56-57.

Amurrio, J.M., A.M. De Ron, and M. Santalla. 1996. Horticultural and potential breeding value of sugar pea landraces from the Northwestern Spain. HortScience 31:843-845.

De Ron, A.M., M. Santalla, J.M. Amurrio, and J.J. Magallanes. 2000. Protocolo de cata para determinación de la calidad de guisante-vaina. Actas Horti.30:31-34. 
Falconer D.S. and T.F.C. Mc Kay. 1996. Introduction to quantitative genetics. 4 th ed. Pearson, Prentice Hall, Harlow, U.K.

Lin C.S., M.R. Binns, and L.P. Lefkovitch. 1986. Stability analysis: Where do we stand? Crop Sci. 26:894-89

McGee, R.J. and J.R. Baggett. 1992. Inheritance of stringless pod in Pisum sativum L. J. Amer. Soc. Hort. Sci. 117:628-632.

Meadley, J.T. and G.M. Milbourn. 1970. The growth of vining peas. J. Agr. Sci. 74:273-278.

Myers, J.R., J.R. Baggett, and C. Lamborn. 2001. Origin, history, and genetic improvement of the snap pea (Pisum sativum L.). Plant Breeding Rev. 21:93-138.

Rohlf, F.J. 2000. NTSYS-pc. Numerical Taxonomy and Multivariate Analysis System. Exeter Software, Dept. Ecology and Evolution, State Univ. N.Y.

Santalla, M., J.M. Amurrio, and A.M. De Ron. 2001. Food and feed potential breeding value of green, dry and vegetable pea germplasm. Can. J. Plant Sci. 81:601-610.

SAS Institute Inc. 2000. SAS/STAT user's guide. version 6. 4th ed. SAS Inst. Inc., Cary, N.C.

Sneddon, J.L. 1970. Identification of garden pea varieties. (I) Grouping, arrangement, and use of continuous characters. J. Natl. Inst. Agr. Bot. $12: 1-16$.

Snoad, B. and A.E. Arthur. 1974. Genotype-environment interactions in peas. Theor. Appl. Genet. 44:222-231.

Steel, R.G.D., J.H. Torrie, andD.A. Dickey. 1997.Principles and procedures of statistics. A biometrical approach. 3rd ed. McGraw-Hill, New York.

Varela, M., J. Hernández, J.M. Amurrio, and A.M. De Ron. 1997. Comparación entre clasificaciones basadas en la variación agronómica e isoenzimática en Pisum sativum. Actas Hort.17:307-313. 